\title{
Comparison of Solea solea macroparasites between two nursery- continental shelf systems in the Bay of Biscay and the Portuguese coast
}

\author{
E. D. H. Durieux ${ }^{\star \dagger}$, J. F. Marques ${ }^{\ddagger}$, P. Sasal ${ }^{\S}$, M-L. Bégout ${ }^{*}$, AND H. N. Cabral ${ }^{\ddagger}$ \\ * Centre de Recherche sur les Ecosystèmes Littoraux Anthropisés, CRELA (UMR 6217 CNRS - \\ IFREMER - Université de La Rochelle), Place du Séminaire, BP5, 17137 L'Houmeau, France. \\ * Instituto de Oceanografia, Universidade de Lisboa, Faculdade de Ciências, Campo Grande, 1749- \\ 016 Lisboa, Portugal. \\ ${ }^{\S}$ Laboratoire de Parasitologie Fonctionnelle et Evolutive, UMR 5555 CNRS-UPVD, Université de \\ Perpignan Via Domitia, 52 Avenue Paul Alduy, 66860 Perpignan, France. \\ ${ }^{\dagger}$ Author to whom correspondence should be addressed. Tel +33 (0) 5465006 25; fax: +33 (0) 546 \\ 5006 00; email: Eric.Durieux@ifremer.fr

\begin{abstract}
:
Digenean metacercariae of 0 year group common sole Solea solea $(n=70)$ were more abundant in the embayed nursery of the Pertuis Charentais than in the Tagus estuary nursery. Macroparasite assemblages of adult sole $(n=119)$ displayed only one species in common between the Bay of Biscay and the Portuguese coast continental shelves. These data highlighted the potential use of macroparasites as biological tags in various aspects of common sole ecology.
\end{abstract}

Keywords: Sole; juvenile; adult; parasites; ecological stock; biological tag. 
The common sole, Solea solea (L.), is a widely distributed flatfish of the northeast Atlantic region, occupying muddy and sandy bottoms from the shore to $200 \mathrm{~m}$ depth (Whitehead et al., 1986). During the breeding period adults congregate in spawning grounds generally located at 50-100 m depth. After a planktonic larval stage, juveniles remain in shallow nursery grounds such as bays and estuaries until sexual maturity is reached at 2-3 years old (Rogers, 1989). This species is economically important, with a consistently high market price and a total annual average landing of 40,000 tonnes in recent years (FAO), with most sole stocks being reported as over-exploited (ICES, 2005). Therefore, understanding target species' population structure is an essential issue for stock assessment and fisheries management.

Parasites reflect many aspects of their fish hosts' biology and ecology, including diet, migration and recruitment (Williams et al., 1992) and can, therefore, be used as biological tags to distinguish fish ecological stocks (MacKenzie, 2002). The term 'ecological stock' is used to describe subpopulations which are distinguished by behavioural differences, but between which there is still a considerable amount of gene flow (MacKenzie, 2002). In fact, studies conducted in the North Atlantic and North Pacific have demonstrated the usefulness of macroparasites as tags for the discrimination of flatfish ecological stocks (Boje et al., 1997; Blaylock et al., 2003; McClelland et al., 2005; Marques et al., 2006a).

Despite their extensive distribution and low genetic population differentiation along the continental shelf (Exadactylos et al., 2003), S. solea habitats are discrete along the Atlantic coast which might result in differences in S. solea macroparasite fauna along its distribution range. In this study, macroparasite infection patterns of juvenile and adult sole have been compared between two different nursery-continental shelf systems belonging to two different management stocks: the Pertuis Charentais-mid Bay of Biscay (France, ICES VIIla,b) and the Tagus estuary-central Portuguese coast (Portugal, ICES IXa), in order to investigate their potential use as biological tags.

The two coastal areas considered (Fig. 1) are recognized as important nursery grounds for their respective sole stock (Cabral \& Costa, 1999; Le Pape et al., 2003). The Pertuis Charentais is an embayed nursery, with a low annual average of freshwater inputs from rivers $\left(10 \mathrm{~m}^{3} \mathrm{~s}^{-1}\right.$ in the Pertuis Breton and 50 $\mathrm{m}^{3} \mathrm{~s}^{-1}$ in the Pertuis d'Antioche) and is thus essentially under sea water influence. On the other hand, the Tagus estuary is a partially mixed estuary, with an annual average river flow of $400 \mathrm{~m}^{3} \mathrm{~s}^{-1}$, the nursery ground of $S$. solea being located in brackish waters (Table I). The two continental shelves under consideration also display strong differences in terms of their topography. The Bay of Biscay is characterized by a wide continental shelf that narrows from 200 $\mathrm{km}$ wide in the north to $30 \mathrm{~km}$ in the south, whereas the central Portuguese coast is characterized by a narrow continental shelf $(15-70 \mathrm{~km})$ cut by deep submarine canyons with the widest area being located north of the Tagus estuary (Fig. 1). 
S. solea 0-group juveniles $(n=70)$ were collected by beam trawl during summer (July-August 2005), when they were concentrated in the nursery grounds (Fig. 1). Adults $(n=119)$ were collected from commercial fishing vessels during winter (February 2005), the spawning period for the two studied areas, using bottom trawl (Bay of Biscay) and gill nets (Portuguese coast). Total length $\left(L_{T}\right)$ was measured (1 $\mathrm{mm}$ precision) for each sampled individual (Table I). No significant difference in $L_{T}$ was detected between the two 0-group samples nor between sexes within each sample (Mann-Whitney $U$-test, $P>$ 0.05 ) (Table I). Although the size range was wider for adults sampled in the Bay of Biscay, those from the Portuguese coast were significantly larger (MannWhitney U-test, $n_{1}=77, n_{2}=37, P<0.05$ ) (Table I). In the Bay of Biscay, $L_{T}$ was significantly higher for females than for males (Mann-Whitney U-test, $n_{1}=$ $41, n_{2}=36, P<0.001$ ) whereas on the Portuguese coast no significant difference between sexes was detected for $L_{T}$ (Mann-Whitney $U$-test, $P>0.05$ ) (Table I). However, we note the high proportion of males in the Portuguese coast sample with only 5 females on the 43 sampled individuals. Based on their size range, all sampled adults were believed to be at least 3 years old.

0-group sole were thawed and their entire body dissected to check for macroparasites, especially digenean metacercariae (in muscle tissue), which were identified and counted. It is known that in summer digenean metacercariae infection is stabilized (Durieux et al., 2006). For adults, the whole Portuguese sample and a subsample of 10 individuals from the Bay of Biscay were checked for metacercariae in muscle tissue but none was found. Gills and digestive tract of adult sole were dissected and checked for macroparasites, which were counted and identified. Sole acquire macroparasites progressively in their digestive tracts while feeding on the intermediate hosts of these parasites (Papoutsoglou \& Papaparaskeva-Papoutsoglou, 1977). The parasitological indices of prevalence (the percentage of infected fish), mean abundance (the mean number of parasites per fish) and mean intensity (mean number of parasites per infected fish) were calculated in each sample according to Bush et al. (1997). As juveniles and adults were respectively sampled during the same season, temporal dynamics of the infection could not interfere in our comparison within each stage.

Cercariae, shed from molluscan first intermediate hosts, penetrate through the skin of the second intermediate host, encysting as metacercariae especially in muscle tissue for the species found in this study. 0-group sole from the two nurseries presented the same digenean metacercariae species in their assemblage: Timoniella spp. (Acanthostomidae), Prosorhynchus aculeatus and P. crucibulum (Bucephalidae) (Table II). Timoniella spp. complex comprise $T$. praeterita and $T$. imbutiforme in the study area. These data suggested that the two nurseries were within the same host-parasite biogeographic area. No relationship was detected between $L_{T}$ and abundance for these species (Spearmann rank order correlation, $P>0.05$ ). No significant differences were found in parasite abundances between sexes within the Pertuis Charentais and the Tagus estuary (Mann-Whitney $U$-test, $P>0.05$ ). However, values of macroparasite mean abundances were significantly higher in the Pertuis Charentais (Mann-Whitney U-test, $n_{1}=40, n_{2}=30$ : Timoniella spp., $P<0.001$; $P$. aculeatus, $P<0.001 ; P$. crucibulum, $P<0.01$ ) (Table II). 
Such discrepancy found between infection levels denoted the role played by environmental differences between embayed and estuarine nursery grounds, and thus the behaviour of sole juveniles. Infection by digenean metacercariae is mainly influenced by the availability of the molluscan first intermediate hosts (Durieux et al., 2006). For the species found in the present study, the mussel Mytilus spp. is the first intermediate host of Prosorhynchus crucibulum (Matthews, 1973) and the laver spire shell Hydrobia spp. the first intermediate host of Timoniella spp. (Maillard, 1973; Maillard, 1974); the first intermediate host of $P$. aculeatus remains unknown. In the Tagus estuary these molluscs are generally found at the mouth of the estuary, whereas 0-group juveniles concentrate in the uppermost part where salinity is lower (Cabral \& Costa, 1999). Even if some Hydrobia spp. are found in less saline waters of the uppermost part of estuaries, marine digenean parasites should not be able to tolerate these low levels of salinity (Pietrock \& Marcogliese, 2003).

In the Pertuis Charentais, because the small rivers do not allow upstream migration, S. solea 0-group juveniles remain in marine waters (Le Pape et al., 2003). The abundance of the first intermediate hosts in this marine system provides, therefore, an explanation for the local accumulation of digenean metacercariae in this nursery ground (Durieux et al., 2006). Similar results were obtained by El-Darsh \& Whitfield (1999) for the European flounder, Platichthys flesus (L.), juveniles in the Thames estuary where the most infected area with digenean metacercariae was the lower estuary, due to the presence of the first intermediate hosts.

The absence of metacercariae in late stage juveniles (Durieux, unpub) and adults (here) suggested that these parasites are eliminated through the host's immune response or natural death of the metacercariae before they reach their final host. In the Bay of Biscay, adults were infected with four species of Nematoda belonging to two families: the Cuccullanidae Dichelyne minutus and Cucullanus campanae; and the Anisakidae Anisakis sp. and Hystherothylacium sp. (Table III). C. campanae is a widely distributed and specific parasite of $S$. solea that uses the polychaete Nereis spp. as an intermediate host (Koie, 2000). According to this author, Nereis spp. are also the first intermediate hosts for $D$. minutus, which despite being specific to $P$. flesus, has been detected in other hosts, especially in areas where its prevalence and intensity are low (Álvarez et al., 2002).

The Anisakidae, Anisakis sp. and Hysterothylacium sp., are characteristic of cold and/or deep waters and use planktonic euphausiid crustaceans and benthic invertebrates, respectively, as first intermediate hosts. Anisakis sp. and Hysterothylacium sp. were only found in females and significant positive relationship was detected between these species abundance and $L_{T}$ (Spearmann rank order correlation with $n=36, R=0.356, P<0.01 ; R=0.438$, $P<0.001$; respectively). The finding of these macroparasites only in females from the Bay of Biscay, where the water temperature is lower than in Portuguese waters, may thus be related to the parasite's ecology but also to that of the host. Given that Anisakidae are found in other fishes off the Portuguese coast (Marques et al., 2006b), the differences detected between the two areas and sexes might be due to differences in common sole ecological patterns in spatial partitioning and feeding habits between areas. Females being much bigger than males in the Bay of Biscay is consistent with increase in 
abundance of anisakidae parasites with host age and length (Tolonen \& Karlsbakk, 2003). But the fact that they were only found in females may also reflect differences in diet between males and females, as already reported for Mediterranean soles by Molinero \& Flos (1991). The much wider continental shelf in the Bay of Biscay, with depth increasing progressively, may allow adults to go deeper on this shelf and prey on a less diverse prey assemblage that might be mostly infected by nematodes.

On the Portuguese coast, adult sole exhibited a more diverse macroparasite fauna: one digenean, Macvicaria soleae (Opecoealidae), two cestodes, Nybelinia lingualis (Tentaculariidae) and Scolex pleuronectis (Tetraphyllidea incertae sedis), one acanthocephalan, Acanthocephaloides propinquus (Arhythmacanthidae), one nematode, C. campanae, and one copepod, Bomolochus soleae (Bomolochidae) (Table III). No significant differences in macroparasite mean abundances were detected between sexes (Mann-Whitney $U$-test, $P>0.05$ ). A significant positive relationship was detected between $L_{T}$ and $C$. campanae abundance (Spearmann rank order correlation, $n=37, R=0.346, P<0.05)$. Prevalence and mean abundance of parasites were generally low in both sites, with values below $30.0 \%$ and 0.6 , respectively, except for the copepod $B$. soleae in the Portuguese coast which reached $59.5 \%$ and 1.1 (Table III). There was no significant difference in mean abundance of $C$. campanae for the two samples, (Mann-Whitney $U$-test, $P>$ 0.05 ) (Table III). A higher level of consumption of molluscs and crustaceans in coastal waters, probably explains the presence of the macroparasites $M$. soleae (Trematoda), N. lingualis, S. pleuronectis (Cestoda) and A. propinquus (Acanthocephala) in the Portuguese coast sample only. Whilst M. soleae and $S$. pleuronectis life-cycles include molluscs and crustaceans as intermediate hosts (Álvarez et al., 2002), N. lingualis and A. propinquus have been found to require amphipods as intermediate hosts (Dollfus, 1976). The finding of ectoparasites (Copepoda) in the Portuguese coast might be related to environmental conditions, especially water temperature, given that for parasites with direct life cycles these are the main factors controlling for infection success (MacKenzie \& Abaunza, 1998). Also, as this ectoparasite is essentially found in coastal environments, it could be related to the more coastal distribution of sole in the Portuguese coast due to its narrow continental shelf. In contrast to the Bay of Biscay, the depth of the Portuguese coast continental shelf increases rapidly, which may limit the distribution of adult sole to shallower areas.

In the Muros estuary (Galicia, northwest Spain) which is located more or less half way between the two considered areas in the present study, Álvarez et al. (2002) found a diverse assemblage of abdominal macroparasites characterized by six species of Digenea and two species of Cestoda, with only two species in common with adults from the Portuguese coast and none with those from the Bay of Biscay. Although, Álvarez et al. (2002) did not report size range for the fish they examined, most of these individuals were likely to be juveniles (between 1 and 3 years old at most), since they were sampled in the inner third of the Muros estuary. Thus, the differences found in macroparasites assemblage between Álvarez et al. (2002) study and the present might be related to differences in prey availability and feeding habits of sole between the three areas but also between estuaries and the continental shelf as pointed out 
by Molinero \& Flos (1991) in the Mediterranean sea. These results suggest the acquisition of different abdominal macroparasites through the lifespan of the host, reflecting the different inhabited habitats. It also highlights the fact that within the same stock management area of the Portuguese coast (ICES IXa) different ecological stocks of sole may exist which is in agreement with what has been shown for other flatfishes off the Portuguese coast (Marques et al., 2006a).

In conclusion, this study demonstrated that macroparasites may reflect the habitat in which their sole hosts live and have lived through their life-span. They are therefore good indicators of the biology and ecology of both stages (juvenile and adult) of the common sole. Digenean metacercariae revealed the difference in the behaviour of 0-group juveniles between estuarine and embayed nursery areas and can be used as tags to infer migrations and habitat use of 0-group juveniles. Macroparasites infecting the gills and the digestive tracts of adults can also be used as tags to discriminate ecological stocks as they reflect differences in habitat and feeding habits of their hosts. A more detailed study including other sampling areas along the European Atlantic coast and focusing on the dynamics of the acquisition of macroparasites through the life cycle of sole is needed to assess stock boundaries and the relative contribution of the different nurseries to a specific stock. 


\section{Acknowledgements}

This study was partly financed by the Ph.D. grants to J.F. Marques (Grant SFRH/BD/ 8983/ 2002), by Fundação para a Ciência e a Tecnologia, Portugal, and to E.D.H. Durieux, by IFREMER and the Conseil Régional Poitou Charentes. This study was co-funded by the European Union through the FEDER - Fisheries Programme (MARE) and France through the PNEC (Programme National Environnement Côtier). We thank Y. Descatoires for Fig. 1. We are grateful to N. Campbell from the FRS Marine Laboratory, Aberdeen, UK, and the two anonymous reviewers for comments on and corrections to the manuscript. 


\section{References}

Álvarez F., Iglesias R., Parama A. I., Leiro J., Sanmartin M. (2002). Abdominal macroparasites of commercially important flatfishes (Teleostei: Scophthalmidae, Pleuronectidae, Soleidae) in northwest Spain (ICES IXa). Aquaculture 213, 31-53.

Blaylock R. B., Margolis L., Holmes J. C. (2003). The use of parasites in discriminating stocks of Pacific halibut (Hippoglossus stenolepis) in the northeast Pacific. Fishery Bulletin 101, 1-9.

Boje J., Riget F., Koie M. (1997). Helminth parasites as biological tags in population studies of Greenland halibut (Reinhardtius hippoglossoides (Walbaum)), in the north-west Atlantic. ICES Journal of Marine Science $54,886-895$.

Bush A. O., Lafferty K. D., Lotz J. M., Shostak A. W. (1997). Parasitology meets ecology on its own terms: Margolis et al. revisited. Journal of Parasitology 83, 575-583.

Cabral H. N., Costa M. J. (1999). Differential use of nursery areas within the Tagus estuary by sympatric soles, Solea solea and Solea senegalensis. Environmental Biology of Fishes 56, 389-397.

Dollfus R. (1976). Enumération des Cestodes du plancton et des invertébrés marins. 9e contribution. Annales de Parasitologie Humaine et Comparée $51,207-230$.

Durieux E. D. H., Galois R., Bégout M.-L., Sasal P., Lagardère F. (2006). Temporal changes in lipid condition and parasitic infection by digenean metacercariae of young-of-year common sole Solea solea (L.) in an Atlantic nursery ground (Bay of Biscay, France). Journal of Sea Research (in press). DOI 10.1016/j.seares.2006.1008.1006.

El-Darsh H. E. M., Whitfield P. J. (1999). Digenean metacercariae (Timoniella spp., Labratrema minimus and Cryptocotyle concava) from flounder, Platichthys flesus, in the tidal Thames. Journal of Helminthology 73, 103113.

Exadactylos A., Geffen A. J., Panagiotaki P., Thorpe J. P. (2003). Population structure of Dover sole Solea solea: RAPD and allozyme data divergence in European stocks. Marine Ecology Progress Series 246, 253-264.

ICES (2005). Report of the ICES Advisory Committee on Fishery Management, Advisory Committee on the Marine Environment and Advisory Committee on Ecosystems, 2005. Volumes 1 - 11. 1. pp. 418 pp. ICES Advice, ICES.

Koie M. (2000). Life cycle of the flatfish nematode Cucullanus heterochrous. Journal of Helminthology 74, 323-328.

Le Pape O., Chauvet F., Mahevas S., Lazure P., Guérault D., Désaunay Y. (2003). Quantitative description of habitat suitability for the juvenile common sole (Solea solea, L.) in the Bay of Biscay (France) and the contribution of different habitats to the adult population. Journal of Sea Research 50, 139-149.

MacKenzie K., Abaunza P. (1998). Parasites as biological tags for stock discrimination of marine fish: a guide to procedures and methods. Fisheries Research 38, 45-56.

MacKenzie K. (2002). Parasites as biological tags in population studies of marine organisms: an update. Parasitology 124, 153-163. 
Maillard C. (1973). Etude du cycle évolutif du Trématode Acanthostomum imbutiforme (Molin, 1859) Gohar, 1934, parasite of Morone labrax (Linne, 1758). Annales de Parasitologie Humaine et Comparée 48, 33-46.

Maillard C. (1974). Cycle évolutif de Timoniella praeteritum (Loss 1901) (Trematoda, Acanthostomidae) parasite de Morone labrax (teleostei, Serranidae). Bulletin de la Société Zoologique de France 99, 245-257.

Marques J. F., Teixeira C. M., Cabral H. N. (2006a). Differentiation of economically important flatfish populations along the Portuguese coast: evidence from morphology and parasitology. Fisheries Research (in press), DOI 10.1016/j.fishres.2006.1005.1021.

Marques J. F., Cabral H. N., Busi M., D'Amelio S. (2006b). Molecular identification of Anisakis species from Pleuronectiformes off Portuguese coast. Journal of Helminthology 80, 47-51.

Matthews R. A. (1973). The life-cycle of Prosorhynchus crucibulum (Rudolphi, 1819 Odhner, 1905, and a comparison of its cercaria with that of Prosorhynchus squamatus Odhner, 1905. Parasitology 66, 133-164.

McClelland G., Melendy J., Osborne J., Reid D., Douglas S. (2005). Use of parasite and genetic markers in delineating populations of winter flounder from the central and south-west Scotian Shelf and north-east Gulf of Maine. Journal of Fish Biology 66, 1082-1100. doi: 10.1111/j.10958649.2005.00659.x

Molinero A., Flos R. (1991). Influence of sex and age on the feeding habits of the common sole Solea solea. Marine Biology 111, 493-501.

Papoutsoglou S. E., Papaparaskeva-Papoutsoglou E. G. (1977). Metazoan parasites of Solea solea (L.) from Porto-Lago, North Aegean sea, Greece. Memorie di Biologia Marina e di Oceanografia 7, 21-33.

Pietrock M., Marcogliese D. J. (2003). Free-living endohelminth stages: at the mercy of environmental conditions. Trends in Parasitology 19, 293-299.

Rogers S. I. (1989). The ecology of juvenile Dover sole Solea solea L.: a review of literature. Progress in Underwater Science 14, 53-66.

Tolonen A., Karlsbakk E. (2003). The parasite fauna of the Norwegian spring spawning herring (Clupea harengus L.). ICES Journal of Marine Science 60, 77-84.

Whitehead P. J. P., Bauchot M.-L., Hureau J.-C., Nielsen J., Tortonese E. (Eds.) (1986). Fishes of the North-eastern Atlantic and Mediterranean. UNESCO, Paris, 1473 pp.

Williams H., MacKenzie K., McCarthy A. (1992). Parasites as biological indicators of the population biology, migrations, diet and phylogenetics of fish. Reviews in Fish Biology and Fisheries 2, 144-176.

\section{Electronic references}

FAO: http://www.fao.org/figis/servlet/FiRefServlet?ds=species\&fid=3367 
Table I. Water parameters (salinity and temperature) during the sampling period of 0-group juveniles and adults of Solea solea in the two different nurserycontinental shelf systems (Pertuis Charentais-Bay of Biscay; Tagus estuaryPortuguese coast); number of individuals $(n)$, mean total length \pm standard deviation (mean $L_{T} \pm$ S.D.), size range in $L_{T}$ ( $\min$ - max) for total, male and female samples of each life stage collected in each location.

\begin{tabular}{|c|c|c|c|c|}
\hline & \multicolumn{2}{|c|}{$\begin{array}{l}\text { 0-group juveniles } \\
\text { Summer } 2005\end{array}$} & \multicolumn{2}{|c|}{$\begin{array}{c}\text { Adults } \\
\text { Winter } 2005 \\
\end{array}$} \\
\hline & Pertuis Charentais & Tagus estuary & Bay of Biscay & Portuguese coast \\
\hline \multicolumn{5}{|l|}{ Water parameters } \\
\hline Temperature $\left({ }^{\circ} \mathrm{C}\right)$ & 19 & 25 & 11 & 13 \\
\hline Salinity & 30 & 14 & 35 & 35 \\
\hline \multicolumn{5}{|l|}{ Total sample } \\
\hline$n$ & 40 & 30 & 77 & 42 \\
\hline Mean $L_{\mathrm{T}} \pm$ S.D. (mm) & $84.7 \pm 7.9$ & $93.3 \pm 17.2$ & $318.7 \pm 60.9$ & $324.7 \pm 31.1$ \\
\hline Size range $(\mathrm{mm})$ & $(70-100)$ & $(61-129)$ & $(250-510)$ & $(238-415)$ \\
\hline \multicolumn{5}{|l|}{ Male sample } \\
\hline$n$ & 34 & 13 & 41 & 37 \\
\hline Mean $L_{\mathrm{T}} \pm$ S.D. $(\mathrm{mm})$ & $85.6 \pm 7.6$ & $92.1 \pm 18.7$ & $280 \pm 22.4$ & $323.3 \pm 32.3$ \\
\hline Size range (mm) & $(72-100)$ & $(61-128)$ & $(250-350)$ & $(238-415)$ \\
\hline \multicolumn{5}{|l|}{ Female sample } \\
\hline$n$ & 6 & 13 & 36 & 5 \\
\hline Mean $L_{\mathrm{T}} \pm$ S.D. (mm) & $79.8 \pm 9.5$ & $95.3 \pm 18.6$ & $362.8 \pm 62.0$ & $336.0 \pm 24.2$ \\
\hline Size range $(\mathrm{mm})$ & $(70-91)$ & $(70-129)$ & $(260-510)$ & $(318-371)$ \\
\hline
\end{tabular}

NB: four 0-group individuals from the Tagus estuary could not be sexed and five adults from the Portuguese coast could not be sized. 
Table II. Prevalence (P (\%)), mean abundance (Ab \pm S.E.) and mean intensity (I \pm S.E. (max)) of the digenean metacercariae of 0-group juveniles Solea solea from the two nursery grounds (Pertuis Charentais and Tagus estuary).

\begin{tabular}{|c|c|c|c|c|c|c|}
\hline \multirow[b]{2}{*}{ Parasite taxa } & \multicolumn{3}{|c|}{ Pertuis Charentais } & \multicolumn{3}{|c|}{ Tagus estuary } \\
\hline & $\mathrm{P}(\%)$ & $\mathrm{Ab} \pm$ S.E. & $\mathrm{I} \pm$ S.E. $(\max )$ & $\mathrm{P}(\%)$ & $\mathrm{Ab} \pm$ S.E. & $\mathrm{I} \pm$ S.E. $(\max )$ \\
\hline \multicolumn{7}{|l|}{ Digenea } \\
\hline Prosorhynchus crucibulum & 57.5 & $1.93 \pm 0.49$ & $3.35 \pm 1.71(13)$ & 16.7 & $0.70 \pm 0.47$ & $4.20 \pm 0.35$ (14) \\
\hline Prosorhynchus aculeatus & 97.5 & $14.18 \pm 1.70$ & $14.54 \pm 0.72(40)$ & 6.7 & $0.10 \pm 0.07$ & $1.50 \pm 2.22(2)$ \\
\hline Timoniella spp. & 62.5 & $8.85 \pm 3.61$ & $14.16 \pm 5.34(102)$ & 20.0 & $0.5 \pm 0.21$ & $2.50 \pm 0.57(5)$ \\
\hline
\end{tabular}


Table III. Prevalence $(P(\%))$, mean abundance (Ab \pm S.E.) and mean intensity $(\mathrm{I} \pm$ S.E. (max)) of the macroparasite species of adult Solea solea from the two continental shelves (Bay of Biscay and Portuguese coast).

\begin{tabular}{|c|c|c|c|c|c|c|}
\hline \multirow[b]{2}{*}{ Parasite taxa } & \multicolumn{3}{|c|}{ Bay of Biscay } & \multicolumn{3}{|c|}{ Portuguese coast } \\
\hline & $\mathrm{P}(\%)$ & $\mathrm{Ab} \pm \mathrm{S} . \mathrm{E}$ & I (max) & $\mathrm{P}(\%)$ & $\mathrm{Ab} \pm \mathrm{S} . \mathrm{E}$. & $\mathrm{I} \pm$ S.E. $(\max )$ \\
\hline \multicolumn{7}{|l|}{ Nematoda } \\
\hline Anisakis sp. & 9.1 & $0.14 \pm 0.06$ & $1.57 \pm 0.28(3)$ & - & - & - \\
\hline Hystherothylacium sp. & 11.7 & $0.23 \pm 0.10$ & $2.00 \pm 0.52(6)$ & - & - & - \\
\hline Dichelyne minutus & 5.2 & $0.06 \pm 0.03$ & $1.25 \pm 0.22(2)$ & - & - & - \\
\hline Cullanus campanae & 26.0 & $0.51 \pm 0.12$ & $1.95 \pm 0.24(5)$ & 28.6 & $0.43 \pm 0.13$ & $1.50 \pm 0.25(4)$ \\
\hline \multicolumn{7}{|l|}{ Digenea } \\
\hline Macvicaria soleae & - & - & - & 4.8 & $0.24 \pm 0.21$ & $5.00 \pm 2.83(9)$ \\
\hline \multicolumn{7}{|l|}{ Cestoda } \\
\hline Nybelinia lingualis & - & - & - & 7.1 & $0.09 \pm 0.06$ & $1.33 \pm 0.27(2)$ \\
\hline Scolex pleuronectis & - & - & - & 2.4 & $0.05 \pm 0.05$ & $2.00 \pm 0.00(2)$ \\
\hline \multicolumn{7}{|l|}{ Acanthocephala } \\
\hline Acanthocephaloides propinquus & - & - & - & 2.4 & $0.05 \pm 0.05$ & $2.00 \pm 0.00(2)$ \\
\hline \multicolumn{7}{|l|}{ Copepoda } \\
\hline Bomolochus soleae & - & - & - & 59.5 & $1.12 \pm 0.19$ & $1.88 \pm 0.20(4)$ \\
\hline
\end{tabular}




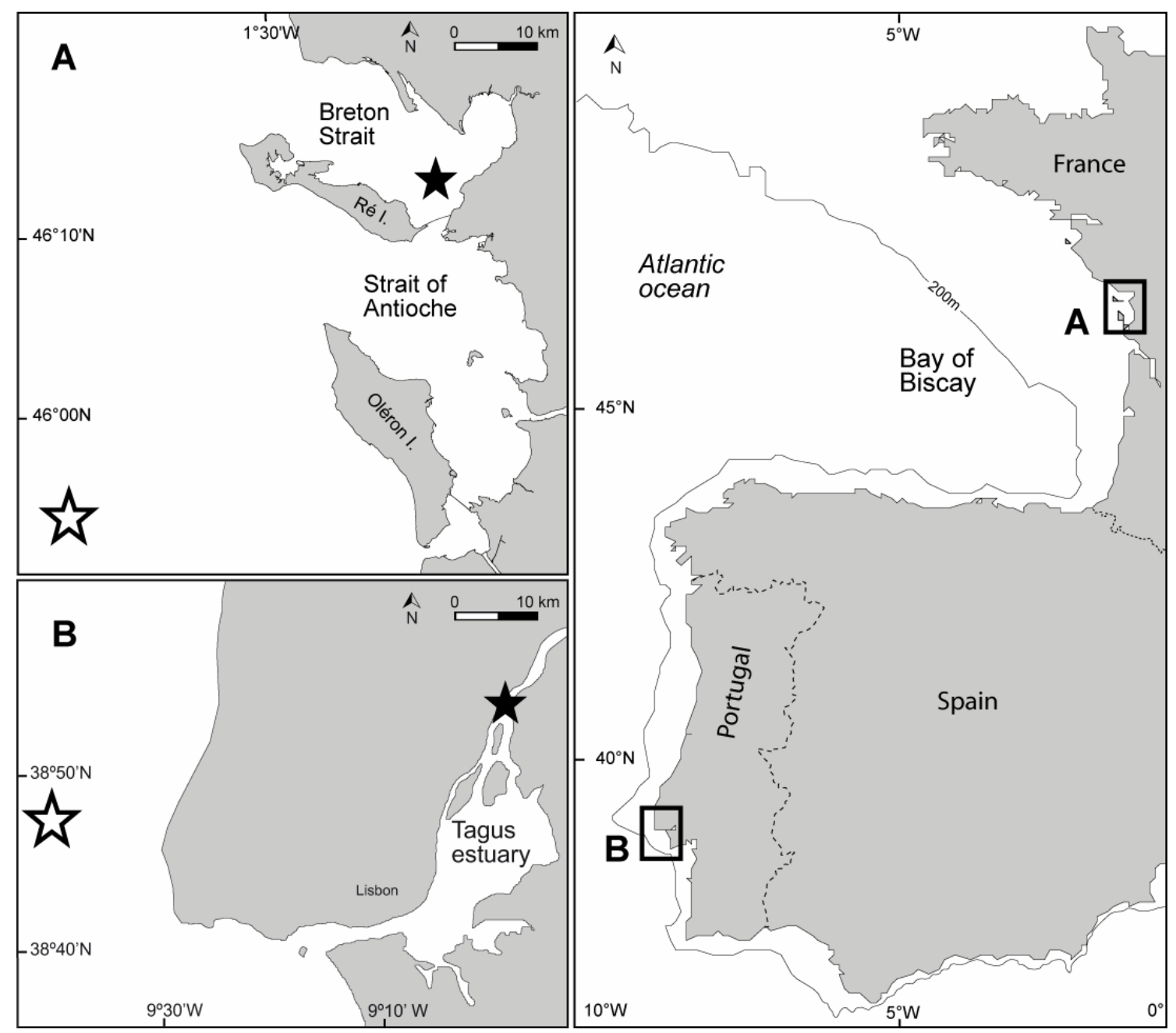

Figure 1. Location of the sampling stations for juvenile (black stars) and adult (white stars) common sole, Solea solea, in the two nursery-continental shelf systems: Pertuis Charentais-Bay of Biscay (France) (A); Tagus estuary-central Portuguese coast (Portugal) (B) 